\title{
MECHANISMS OF ENDOCRINOLOGY Cell cycle regulation in adrenocortical carcinoma
}

\author{
Sofia S Pereira1,2,3, Mariana P Monteiro3 ${ }^{3}$, Isabelle Bourdeau4, André Lacroix ${ }^{4}$ and Duarte Pignatelli',2,5 \\ 'Instituto de Investigação e Inovação em Saúde (I3S), Universidade do Porto, Porto, Portugal, 'Institute of Molecular \\ Pathology and Immunology of the University of Porto (IPATIMUP), Porto, Portugal, ${ }^{3} \mathrm{Clinical}$ and Experimental \\ Endocrinology, Department of Anatomy, Multidisciplinary Unit for Biomedical Research (UMIB), Instituto de Ciências \\ Biomédicas Abel Salazar, University of Porto (ICBAS/UP), Porto, Portugal, ${ }^{4}$ Endocrinology Division, Department of \\ Medicine, Centre de Recherche du Centre Hospitalier de I'Université de Montréal (CHUM), Montréal, Canada, and \\ ${ }^{5}$ Department of Endocrinology, Hospital S. João, Porto, Portugal \\ Correspondence \\ should be addressed \\ to D Pignatelli \\ Email \\ dpignatelli@yahoo.com
}

\begin{abstract}
Adrenocortical carcinomas (ACCS) are rather rare endocrine tumors that often have a poor prognosis. The reduced survival rate associated with these tumors is due to their aggressive biological behavior, combined with the scarcity of effective treatment options that are currently available. The recent identification of the genomic alterations present in ACC have provided further molecular mechanisms to develop consistent strategies for the diagnosis, prevention of progression and treatment of advanced ACCs. Taken together, molecular and genomic advances could be leading the way to develop personalized medicine in ACCs similarly to similar developments in lung or breast cancers. In this review, we focused our attention to systematically compile and summarize the alterations in the cell cycle regulation that were described so far in ACC as they are known to play a crucial role in cell differentiation and growth. We have divided the analysis according to the major transition phases of the cell cycle, G1 to $S$ and $G 2$ to $M$. We have analyzed the most extensively studied checkpoints: the p53/Rb1 pathway, CDC2/cyclin B and topoisomerases (TOPs). We reached the conclusion that the most important alterations having a potential application in clinical practice are the ones related to $\mathrm{p} 53 / \mathrm{Rb} 1$ and TOP 2 . We also present a brief description of on-going clinical trials based on molecular alterations in ACC. The drugs have targeted the insulin-like growth factor receptor 1, TOP 2, polo-like kinase1, cyclin-dependent kinase inhibitors, p53 reactivation and CDC25.
\end{abstract}

\section{Introduction}

Adrenocortical carcinomas (ACCs) are rather rare tumors, and this constituted a major limitation to conduct wide and comprehensive molecular characterization studies. In spite of this, a relatively large number of studies identified a wide array of molecular alterations, but usually in a relatively limited number of ACC samples.

Molecular studies that aimed to characterize the cell cycle deregulations found in adrenocortical tumors (ACTs) are the subject of this systematic review. This comprehensive review aims to clarify some apparently
European Journal of Endocrinology

(2018) 179, R95-R110

\section{Adrenocortical carcinomas}

ACCs have an annual incidence of 1-2 cases per million persons worldwide $(1,2,3,4,5)$. ACCs can be functional, 
producing hormonal and metabolic syndromes that can occasionally accelerate their identification or are discovered incidentally during imaging for unrelated clinical reasons $(4,6)$. In some patients with very large tumors, the symptoms of abdominal discomfort or pain due to the mass effect will lead to adrenal imaging and diagnosis. The detection of non-functioning ACTs (both benign and malignant) increased significantly over the last years, due the widespread use of CT, MRI and abdominal ultrasonography $(6,7)$.

The potentially dark prognosis of ACC is very different from adrenocortical adenomas (ACAs), which stresses the importance of differential diagnosis between the two entities $(8,9)$. However, the evaluation of the potential malignant evolution of ACTs is not always easy to assess. So far, the size and morphological characteristics of the lesion on the imaging studies is the initial strongest predictor of the adrenocortical malignant potential; according to the European Society of Endocrinology Clinical Practice Guideline (10), unilateral ACTs larger than $6 \mathrm{~cm}$ should be treated surgically. Those between 4 and $6 \mathrm{~cm}$ should undergo additional imaging investigation to better define malignant potential. In addition to size, a threshold value of 10 Hounsfield units (HU) of unenhanced CT scan was shown to have a high specificity and sensibility for the differential diagnosis of adrenocortical malignant lesions $(10,11)$. After tumor removal, the pathological diagnosis includes evaluation of tumor macroscopic characteristics, again including size, but also the presence of an intact capsule, areas of necrosis and hemorrhage, adjacent organ invasion and lymph node metastasis. At the microscopic level, the modified Weiss scoring system helps in the assessment of malignancy potential whenever metastasis has not been identified $(12,13)$. A few molecular and immunohistochemistry markers are also helpful to define ACC diagnosis $(11,13,14)$. The major alterations found in the ACCs are the overexpression of IGF- 2 and the constitutive activation of the Wnt/ $\beta$-catenin pathway. Although the former one was identified as a useful marker for ACC by several authors, it was not yet validated to be used in clinical practice. Ki-67 proliferation index has also been found to be an important marker for the prediction of recurrence (15), and it is used to guide the management of ACC patients.

The disease stage and margin-free resection are among the major prognostic factors in ACC $(16,17)$. The stage classification proposed by the European Network for the Study of Adrenal Tumors (ENSAT) in 2009 is the most accurate to define ACC prognosis $(5,17)$. This staging system, defines stage I and stage II as localized tumors with a size of $\leq 5$ or $>5 \mathrm{~cm}$ respectively. Stage III ACCs present infiltration in surrounding tissue or regional lymph, whereas stage IV is characterized by the presence of distant metastasis. Using ENSAT classification, the 5 -year disease-specific survival rate is approximately $82 \%$ for stage I, $61 \%$ for stage II, 50\% for stage III and 13\% for stage IV (17). The high proportion of ACC is diagnosed in an advanced stage leading to a poor prognosis (4). The secretion of abnormal levels of steroids by ACCs also confers substantial morbidity (18).

The behavior of ACCs differs between patients. Almost $50 \%$ of stage I and II adrenal carcinomas will not be cured by surgery even when complete marginfree resection is achieved, while others with similar pathological characteristics are cured by surgery and patients remain disease free. Recent studies indicate that prognosis is related to significant variability of tumors at the molecular level (19).

\section{Pan-genomic characterization of ACCs}

Assié et al. and Zheng et al. recently performed comprehensive genomic characterizations of ACCs with the major goal of identifying stratification profiles of ACC patients with distinct clinical outcomes $(20,21)$. The studies include data on gene expression, exome sequencing, miRNA expression, copy number alterations, SNPs, loss of heterozygosity (LOH), mutations, DNA methylation and even protein expression $(20,21)$. Much of this information is not yet translated into complete understanding of molecular pathways, but they have confirmed some previous findings and identified potentially very important novel contributing pathogenic alterations.

Using exome sequencing and SNP array analysis, the studies identified recurrent alterations in several genes implicated in the Wnt pathway, cell-cycle regulation, chromatin remodeling and chromosome maintenance, as ACC drivers.

Indeed, the major findings of the integrated pangenomic studies were the identification of distinct ACC molecular subgroups strongly associated with patient's outcome. The subgroup of aggressive ACCs presented higher expression of cell-cycle-related genes and accumulation of more mutations in the ACC drivers.

Based on the methylation on $\mathrm{CpG}$ islands in gene promoter regions, the aggressive ACC group was further divided into two other subgroups: a group of patients with intermediate outcome and a group with the 
poorer outcome, which was characterized by having hypermethylation in those regions $(20,21)$.

\section{Cell cycle}

Since alterations in the cell cycle regulators were pointedout as very important ACC drivers by the already mentioned pan-genomic studies but also by several smaller studies, we decided to gather the current knowledge on cell cycle dysregulation in ACCs in this review.

The cell cycle is a complex process that results in cell division. It includes four distinct phases going from the cell growth, DNA replication, partition and distribution of the duplicated chromosomes and cell division (Fig. 1) (22). This process is regulated by complex intracellular and extracellular signaling cascades that coordinate the different phases of the cell cycle to ensure a successful cell division $(22,23)$. Deregulation of the cell cycle is one of the most frequent events in tumor development. Therefore, elucidation of the underlying mechanisms of its alterations in tumorigenesis could lead to novel therapeutic targets $(24,25)$.

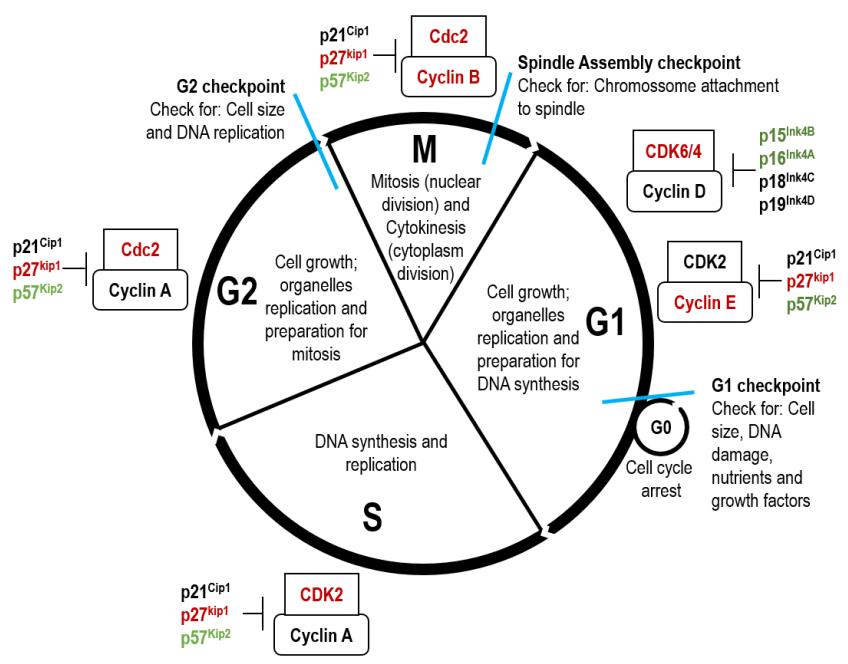

Figure 1

Schematic representation of the mammalian cell cycle. Cell cycle is mainly regulated by cyclin-dependent kinase (CDK): CDK2, CDK4, CDK6 and Cdc2; cyclins (cyclin A, B, D and E) and CDK inhibitors ( $p 15^{\text {Ink4B }}, p 16^{\text {Ink4A }}, p 18^{\text {Ink4C }}, p 19^{\text {Ink4D }}, p 21^{\text {Cip1, }}$ $\mathrm{p} 27^{\mathrm{kip} 1}, \mathrm{p} 57^{\mathrm{kip} 2}$ ). In red are represented the overexpressed cell cycle regulators and in green the underexpressed regulators in ACCs. A full colour version of this figure is available at https:// doi.org/10.1530/EJE-17-0976.
Cell cycle regulation is generally grouped in three waves that correspond to the transition points of the cell cycle: G1 to S; G2 to M and M to G1 (Fig. 1) (26). The majority of the cell cycle regulation alterations in ACCs were found to be present in the G1-to-S and G2-to-M transitions (27).

\section{Alterations in the regulation of G1-to-S phase found in ACCs}

Pan-genomic studies identified the p53-Rb1 pathway as the second most altered pathway found in the ACCs (20, 21), while the first one the Wnt B-catenin pathway is not related to the cell cycle. The p53-Rb1 pathway was already known as the major checkpoint of the G1 phase of the cell cycle. Briefly, in response to DNA damage, ataxia telangiectasia mutated (ATM) or ataxia telangiectasia and Rad3-related protein (ATR) are activated and phosphorylate p53 through Chk1/2. Phosphorylated p53 dissociates from the murine double minute $2(\mathrm{Mdm} 2)$ and is thereby stabilized. Active p53 upregulates the endogenous p21 mRNA and protein levels (28). Overexpression of p21 blocks the phosphorylation of the retinoblastoma protein (pRb) by cyclin E/cyclin-dependent kinase (CDK)2, preventing the E2F-mediated gene expression induction required for cells to enter S phase (29).

Inactivating mutations or homozygous deletion of TP53 (16\%), CDKN2A (11\%) and RB1 (7\%) and high levels of amplification of CDK4 (2\%) and MDM2 (2\%) were found to occur in 40 cases of the 122 ACCs analyzed by Assié et al. (21). These alterations were mainly found in the ACCs with poorer prognosis. Zheng et al. (20) also reported deactivating alterations (mutations and deletions) in TP53 (21\%), CDKN2A (16\%) and RB1 (7\%) and activating alteration in CDK4 (7\%), MDM2 (7\%) and CCNE1 (6\%), the gene that encodes the cyclin E. Altogether, the p53/Rb1 pathway was altered in $44.9 \%$ of the analyzed ACCs by Zheng et al. (20). Since the majority of the TP53 mutations observed affect the DNA-binding domain or the oligomerization domain, these alterations prevent the role of p53 as a tumor suppressor, leading to an important dysfunctionality of the G1 checkpoint. This point, together with a deregulation of the major molecules implicated in the G1 phase: cyclin E, CDK4 and Rb1, will lead to an uncontrolled ACC cell proliferation.

\section{Alterations in p53 pathway in ACCs}

The study of the p53 and their regulators in ACC started many years ago, after the discovery that the 
Li-Fraumeni syndrome confers susceptibility to ACCs and is characterized by the presence of TP53 germline mutations in approximately $71 \%$ of families with that syndrome $(30,31)$. Although germline TP53 mutations were later found to be rare in adult patients with ACC, somatic TP53 mutations were documented to be more frequent $(32,33,34,35,36)$. In a large cohort of adult Caucasian patients with ACC, a 3.9\% prevalence of TP53 germline mutation was found (35); in contrast, $13 \%$ of adult patients (aged $<40$ years), carried a TP53 germline mutation (35). Germline mutations in TP53 were observed in $50-80 \%$ of children with sporadic ACC (37, $38,39)$. Many studies analyzed the presence of somatic TP53 mutation in ACCs and verified that its prevalence varies from 20 to $30 \%$ in sporadic ACCs $(32,34,40)$. The majority of patients with ACC and mutated TP53 had a poor outcome (40).

Mutations of TP53 usually result in loss of p53 protein function. Several studies evaluated p53 expression in ACTs, and it was demonstrated to be absent in the majority of ACAs $(41,42)$. Among ACCs, p53 expression has been found to be highly variable ranging between 5 and $52 \%$, denoting the inadequacy of this marker to identify malignancy in ACT $(41,42,43,44,45)$. Even in childhood ACCs, p53 expression demonstrated no prognostic significance (46).

p53 and MDM2 (mouse double minute 2) form an auto regulatory negative feedback loop allowing the maintenance of low cellular p53 levels in the absence of stress (47). p53 stimulates the expression of MDM2 and MDM2 inhibits p53 activity by promoting its degradation, blocking its transcriptional activity and promoting its nuclear export $(47,48)$. As already described, DNA damage promotes phosphorylation of p53 and MDM2, mediated by ATR and ATM and avoid MDM2-p53 interaction and thus stabilizing p53 (Fig. 2) (47). Protein p19 ${ }^{\mathrm{ARF}}$ also stabilizes p53 by inhibiting the nuclear export of MDM2 by tethering MDM2 in the nucleolus (49).

The amplification of the MDM2 gene was observed in a minority of the human ACCs, as reported by several studies, including the pan-genomic studies (20, $21,50,51,52,53)$. Using the immunohistochemistry technique, MDM2 protein expression showed no differences between ACAs and ACCs $(42,45)$. The underexpression of ATR gene was also observed in ACCs and was associated with poor survival $(27,53)$. Mutations in ATM gene were also described in ACCs by some authors $(50,51)$.

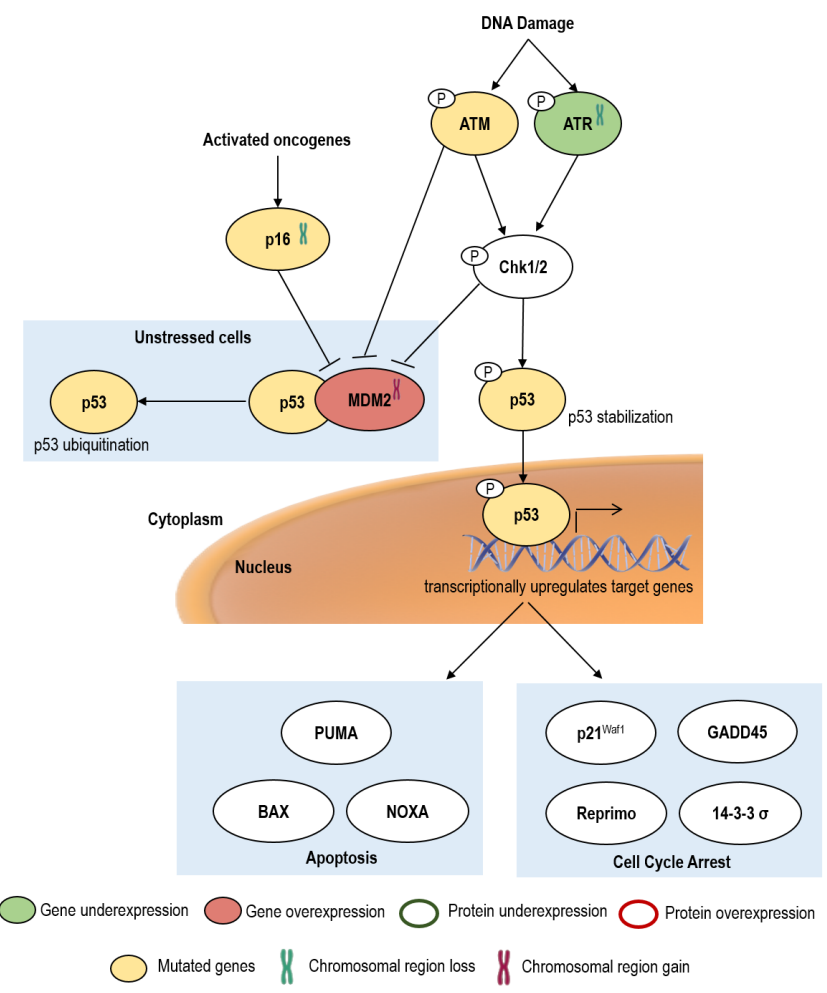

Figure 2

Schematic representation of $\mathrm{p} 53$ regulation. $\mathrm{p} 53$ transcriptional activity is inhibited by MDM2 that promote p53 ubiquitination. DNA damage leads to p53 phosphorylation via ATM/ATR, preventing its association with MDM2. Besides that, p19ARF also inhibits MDM2 preventing p53 ubiquitination. Stabilized p53 goes to the nucleus where it is able to transcriptionally upregulate genes involved in apoptosis and cell cycle arrest. Gene and protein alteration already described in the ACCs are indicated. A full colour version of this figure is available at https://doi.org/10.1530/ EJE-17-0976.

\section{CDK, cyclins and CDKi status in ACCs}

Cell cycle progression from G1 to $\mathrm{S}$ phase is driven by the CDK family of serine/threonine kinases (CDK-2, -4 and $-6)$, their regulatory partners, the cyclins (D and E) and their inhibitors, CDK inhibitors (CDKi) (p15, p16, p21, p27 and p57) $(54,55,56)$.

In the pan-genomic studies $(20,21)$ and in other smaller studies, one of the most frequent DNA copy number changes in ACCs are gains in chromosome (chr)12, combined with the amplification of CDK4 (located at chr12q14.1) and CDK2 (located at chr12q13) $(53,57,58,59,60)$. Reinforcing its importance, gains in chr12q13.2 have been associated with ACCs poor survival 
rates (53). Overexpression of $C D K 2$ and $C D K 4$ has also been reported in ACC (61). At the protein levels, CDK4 and CDK2 overexpression was detected in the human ACC cell line (H295R) and in the majority of the ACCs (62). Schmitt et al. verified that all the ACCs studied presented CDK4-positive staining, but the same occurred in the majority of ACAs; however, ACAs had a very weak positivity when compared to ACCs (63).

Cyclin $\mathrm{E}$ is the regulatory subunit of the cyclin E-CDK2 complex, and together they control the progression through G1 phase $(23,64,65)$. Cyclin E dysregulation is often observed in several tumor cells; it is thought to be involved in the tumorigenesis process and to be an important prognosis marker for some tumors $(64,66,67)$. There are two subtypes of cyclin E, the cyclin E1 and the cyclin E2, encoded by the genes: CCNE1 at chr19q12, and CCNE2 at chr8q22.1, respectively (65). CCNE1 and CCNE2 overexpression and amplification has been reported in ACCs by several authors, including in the recent pan-genomic studies $(20,61,68,69,70,71)$. Overexpression of the cyclin E protein was observed in ACCs and found to be significantly associated with the histologic grade and with shorter disease-free survival $(62,67,71)$.

CDKi are negative regulators of cell cycle progression and potentially act as tumor suppressors, through the inhibition of the cyclin/CDK complexes. The CDKi, p57 is encoded by the CDKN1C gene located at chr11p15.5, where $I G F 2$ is also located $(5,72)$. Genetic rearrangements at the chr11p15.5 are common in ACCs, leading to the well-known phenomenon of IGF2 overexpression $(5,73$, $74,75)$. The majority of ACCs and virilizing ACAs present low p57 and H19 expression and high IGF2 expression (73). In contrast to normal adrenal glands and most ACA where the p57 mRNA is highly expressed, suggesting that p57 has a physiological role in normal adrenal cortex growth, the combination of low p57 and H19 expression and high IGF-2 expression seems to be involved in ACT malignancy (73). Low expression of CDKN1C gene and p57 protein has been found in adult and childhood ACC. This was not due to mutations since no CDKN1C mutations were detected, suggesting that other mechanisms, such as abnormalities of imprinting or methylation, could be responsible for its low expression $(8,34,62,69,76)$. Downregulation of p57 in ACCs was found to be associated with CDK2 increased activity (62).

CDKN2A can encode, by alternative splicing, for $\mathrm{p} 16$, a CDK4/6 inhibitor, and p14, the p53 stabilizer, whereas CDKN2B encodes another CDK4/6 inhibitor, the p15 $(50,77)$. Alterations in both genes, namely the deletion of CDKN2A and CDKN2B, were observed in $14.3 \%$ and $10.7 \%$ of the analyzed ACCs respectively. Allelic losses on chr9p21, where $C D K N 2 A$ and $C D K N 2 B$, are harbored were described $(20,78)$.

p21 and p27 are the CDKis involved in the regulation of cyclin E-CDK2 and cyclin D-CDK4/6 complexes in the G1-S transition (Fig. 1) $(79,80)$. p21 is encoded by CDKN1A gene and its expression is regulated by p53, while p27 is encoded by $C D K N 1 B$ gene, a gene that is rarely mutated in the context of cancer $(79,80,81)$. The p21 protein expression was observed in both benign and malignant ACT, although a significantly higher proportion ACCs presented positive expression (42). Babinska et al. also found an increased expression of p21 in ACCs when compared with ACAs and a significant correlation between its expression and the occurrence of metastasis (82). Still, other studies did not find the significant differences between benign and malignant ACT, and there is evidence that its expression is inconsistent regardless of other molecular abnormalities, similarly to the p53 expression $(34,45)$. Nakazumi et al. observed p27 expression to be decreased in the ACCs when c2ompared with ACAs (83). However, other authors have found opposite results, with increased p27 expression in ACCs when compared to ACAs $(42,45)$.

\section{RB-E2F complex status in ACCs}

In G1 phase, in order to allow the transition to $S$ phase, $\mathrm{CDK}$-cyclin complexes are responsible for the inactivation of the $\mathrm{pRb}$ through phosphorylation (84). Activated $\mathrm{pRb}$ binds to the transactivation domain of E2F to form a pRBE2F complex that changes the chromatin structure at the E2F-responsive promoter by recruiting histone deacetylase to the pRB-E2F complex (Fig. 3) $(84,85)$. Then, this complex binds to the promoter of some genes such as DNA polymerase subunits, cyclin A and cyclin E, which are required for $\mathrm{S}$ phase entry, leading to the transcription repression of those genes, and cell cycle arrest in phase G1 $(84,86)$.

Upregulation of genes with binding sites for E2F seems to be a common event in many tumor types and has also been observed in ACCs $(71,87)$. Gains in the chr20, namely chr20q and chr20q11, where E2F1 is harbored have been reported as a common event in ACCs $(57,58$, 60 ). However, other studies, including the pan-genomic studies, have not reported gains in chr20 as a common occurrence in ACCs $(20,21,88,89)$.

Inactivating mutations, deletions and allelic losses of $R B$ gene were observed in several tumors and seem to 


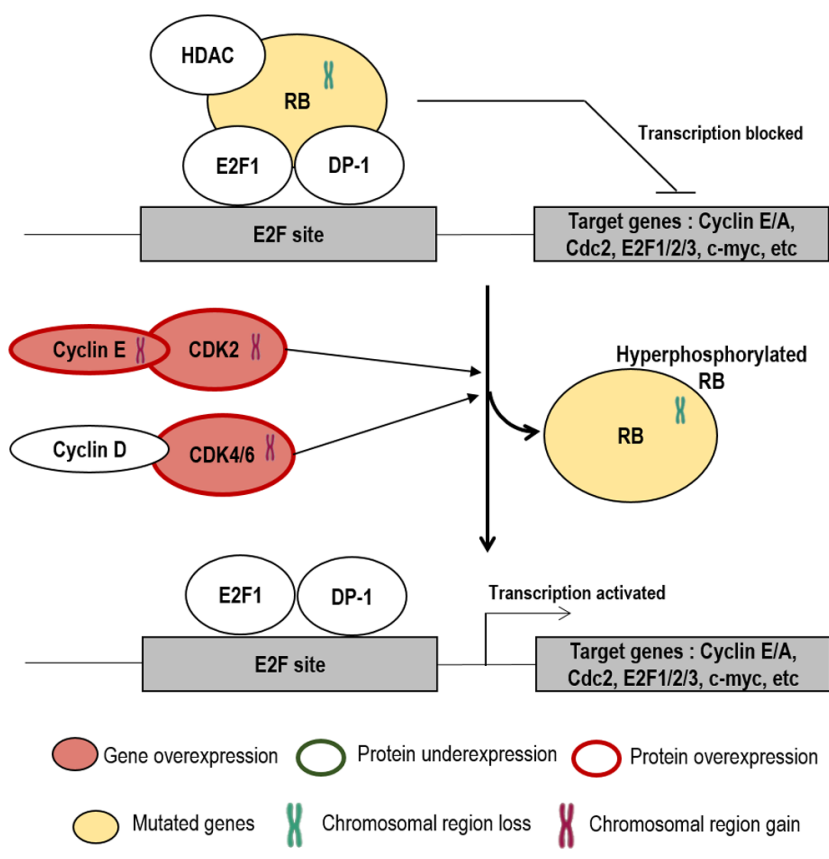

Figure 3

Schematic representation of $\mathrm{Rb}$ regulation.

Hyperphosphorylation of $\mathrm{Rb}$ by the $\mathrm{CDK} /$ cyclin complexes prevents the binding of RB to the transcription factor E2F, allowing the transcription of genes required for $S$ phase entry. Gene and protein alteration already described in the ACCs are indicated. A full colour version of this figure is available at https://doi.org/10.1530/EJE-17-0976.

be associated with an increase in cancer susceptibility $(84,90)$. Ragazzon et al. found that the loss of pRB was exclusively found in the subgroup of aggressive tumors, suggesting that the $R B 1$ has an important role in the last events of the ACC and could be used as a prognostic marker (91). Among the ACCs with pRB loss, the majority presented an allelic loss at the RB1 locus (91). de Fraipont et al. confirmed that mRNA expression of $R B 1$ was reduced in the malignant ACTs (92). Gupta et al. also reported differences in the pRB1 staining between benign and malignant ACTs, whereas among the ACTs studied by Vargas et al., both benign and malignant ACTs, were positive for $\mathrm{pRB1}$, with no differences between these two groups $(93,94)$.

c-Myc is a pivotal regulator of the cell cycle being able to activate and repress pathways affecting G1-to-S phase progression in mammalian cells. c-Myc overexpression leads to the loss of CDK inhibition resulting in the inactivation of $\mathrm{pRb}$ through phosphorylation, release of E2F and cell cycle progression to $S$ phase. Furthermore, c-Myc induces the activity of E2F, directly and subsequently activates transcriptional of DNA synthetic enzymes $(54,95)$.

Amplification of protooncogene $c-m y c$ is frequently observed in a wide variety of human neoplasms through a variety of mechanisms $(95,96)$. In contrast to the observation in the majority of other tumors, several studies revealed that $c-m y c$ is underexpressed in ACCs compared to ACAs and to the normal adrenal cortex (69, $70,71,97,98)$. The location of c-myc protein has also been correlated with ACT malignancy, since ACCs express c-myc both in the cell cytoplasm and nuclei while ACAs only express it in the cell nuclei (99). Since overexpression of c-myc induces cell proliferation and ACCs are rapidly proliferating tumors, c-myc was expected to be overexpressed in ACCs; however, the opposite was found to occur in this type of cancer $(95,97)$.

\section{G2-to-M phase transition in ACCs}

In ACCs, alterations in the G2-to-M transition are less frequently reported than changes in the G1 to S. In addition, these changes were mostly reported in isolated studies and rarely in an integrated approach.

The most important role of the G2 phase is to ensure that the chromosomes have been accurately replicated without mistakes or damages, in order to allow the cycle to progress to mitosis (100).

G2-to-M transition is mainly regulated by the CDK, Cdc2, also known as CDK1 (101, 102). Cdc2 is able to form a complex with either cyclin B or cyclin A (Fig. 1) $(101,103)$.

Cdc2 is activated by a combination of some required steps: (1) the phosphorylation of $\mathrm{Thr}^{161}$ by the Cdkactivating kinase (CAK) in order to open the catalytic region of Cdc2; (2) the nuclear translocation of Cdc2/cyclin B1 complex by the polo-like kinase 1 (Plk1) phosphorylation of Ser ${ }^{147}$ on Cdc2 and (3) the dephosphorylation of $\mathrm{Thr}^{14}$ and $\mathrm{Tyr}^{15}$ by the division 25 (Cdc25) phosphatase family, Cdc25A, Cdc25B and Cdc25C (104, 105, 106, 107).

Activation of Cdc25C is achieved by phosphorylation of Ser ${ }^{198}$ by Plk1, leading to nuclear export of the Cdc25C (107). After that, Cdc25C is hyperphosphorylated by the complex Cdc2-cyclinB1, leading to a positive feedback loop, increasing the Cdc2-cyclinB1 activity (Fig. 4A) (104).

Cdc25 is a dual-specificity phosphatase that not only activates the complexes cyclin B-Cdc2, but also the cyclin A-CDK2 and cyclin E-CDK2 at key cell cycle transitions: the isoform Cdc25A regulates the G1/S transition, whereas 
A
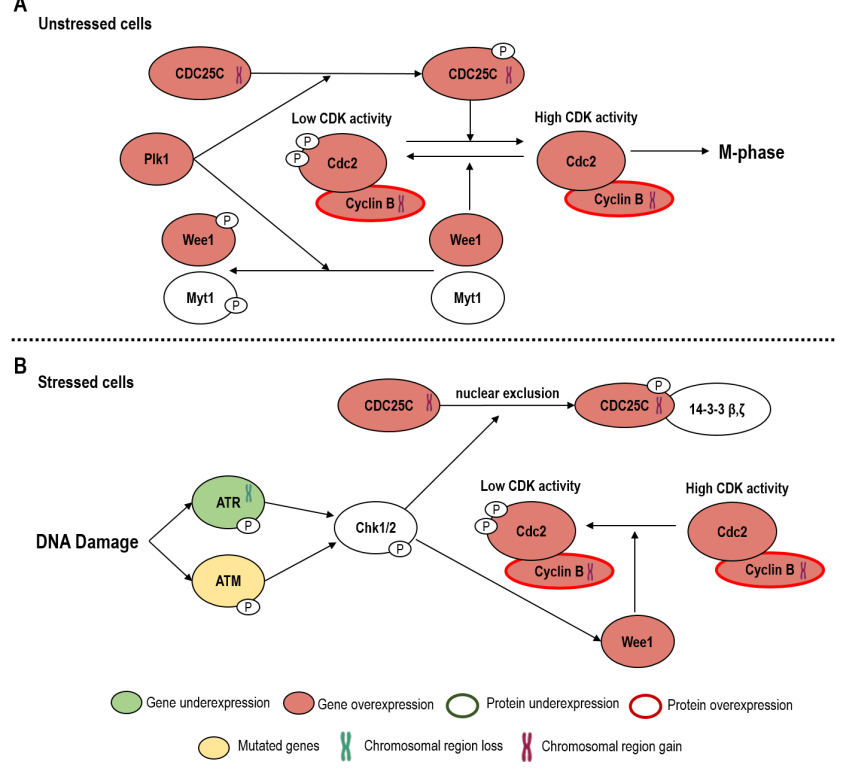

\section{Figure 4}

Schematic representation of $\mathrm{CDC2} / \mathrm{cyclin} \mathrm{B}$ regulation. In unstressed cells, Plk1 phosphorylates Cdc25C, Wee1 and Myt1, leading to $\mathrm{Cdc} 2 / \mathrm{cyclin} B$ activation and entry in the mitosis (A). In the presence of DNA damage, Chk1/2 are phosphorylated via ATM/ATR and are able to induce Cdc25C nuclear exclusion and to activate Wee1, leading to the inactivation of $\mathrm{Cdc} 2 /$ cyclin B and cell cycle arrest (B). Gene and protein alteration already described in the ACCs are indicated. A full colour version of this figure is available at https://doi.org/10.1530/ EJE-17-0976.

the isoforms Cdc25B and Cdc25C act at G2/M, controlling the entry into mitosis $(108,109)$. Inactivation of Cdc25C is reached through phosphorylation of $\operatorname{Ser}^{216}$, creating a binding site for the 14-3-3 protein. Then the Cdc25C goes to the cytoplasm preventing Cdc25C and Cdc2 interaction (Fig. 4B) (104, 110). This phosphorylation is mediated by Chk1, Chk2, C-TAK1 and Plk3 and also through the complexes cyclin B-cdc2 or cyclin A-cdc2 formation (104).

Deregulation of Cdc25 isoforms expression and activity, leading to unrestrained proliferation, has been found in some tumors (108, 109). In ACCs, CDC25 isoforms gene overexpression have been described (27, $69,70)$, in parallel with the gain-of-chromosome region ch5q31.2, where CDC25C is harbored $(111,112)$. The overexpression of CDC2 was also reported in ACCs, by several studies, with a higher expression in the more aggressive cases $(68,69,70,71,113)$. Overexpression of Plk1, the kinase responsible for Cdc2/cyclin B1 complex nuclear translocation and Cdc25c phosphorylation, has been associated with tumor development and considered a possible prognostic marker for some tumors $(114,115$, 116, 117, 118, 119). Furthermore, Plk1 inhibitors are in preliminary tests for tumor treatment (120, 121, 122). Overexpression of PLK1 has been found in ACCs when compared with the non-functioning ACAs, cortisolproducing ACAs and with the normal adrenal glands (69). Plk1 inhibitors, such as the small-molecule BI-2536, have been tested in ACC cell lines, SW-13 and H295R, and found to significantly reduce the tumor cell growth, suggesting that Plk1 inhibitors deserve to be further investigated as a potential therapeutic approach in ACCs $(123,124)$.

Inactivation of the Cdc2-cyclin B complexes, responsible for mitosis initiation is a pre-requisite to exit mitosis (Fig. 1) (101, 102). Cyclin B presents various isoforms: Cyclin B1 that is encoded by CCNB1, cyclin $\mathrm{B} 2$ that is encoded by CCNB2 and cyclin B3, that is the less well-characterized cyclin B, encoded by CCNB3 (125, 126). Overexpression of CCNB1 or the correspondent chromosome gains were described in ACCs comparing to ACAs and normal adrenal glands $(27,69,70,113$, 127). Cyclin B1 protein expression was also found to be increased in ACCs but in spite of a high specificity (100\%), it had a low sensitivity (43\%) for predicting malignancy. In consequence, cyclin B1 is only useful for confirming malignancy but is not helpful for its exclusion it when it is negative (113).

CCNB2 overexpression was also found in ACCs, particularly in the more aggressive forms. However, the correspondent chromosomal alterations were not observed $(27,69,70,127)$.

The Myelin Transcription Factor 1 (Myt1) and Wee1 are proteins able to inhibit the Cdc2, through inhibitory phosphorylation at $\mathrm{Thr}^{14}$ and $\mathrm{Tyr}^{15}$ (Fig. 4) (100, 109, 128, 129). Once activated, cyclin B-Cdc2 complexes phosphorylate Wee1 and Myt1 to promote their inactivation, allowing an even larger amplification of Cdc2 activation (106). Wee1 is predominantly a nuclear protein that has been found to associate with centrosomes, whereas Myt1 is present in the cytoplasm bound to membrane structures $(128,130)$. WEE1 gene overexpression has been found in ACCs when compared with ACAs and normal adrenal glands (68), but there was no MYT1 gene overexpression in ACCs (69).

Topoisomerases (TOPs) are enzymes that are involved in the biological processes that require strand unwinding, such as replication, transcription and maintenance of genome stability, as they are able to introduce transient breaks in DNA $(131,132)$. The TOP1 introduces single-strand breaks in the DNA, and TOP2 introduces double-strand 
breaks. Type II TOPs are required to segregate replicated chromosomes $(131,133)$. TOP2A, is a TOP2 isoform, present only in the S, G2 and M phases of the cell cycle of proliferating tissues $(131,133)$. Several authors confirmed TOP $2 A$ overexpression in ACCs $(61,68,69,70,71,127)$, which was associated with higher ACC aggressiveness (70). TOP2A protein overexpression was associated with significantly poorer overall and disease-free survival (93, $134,135,136)$. Iino et al. have also suggested that TOP2A could be an even better proliferation marker than Ki-67, since some cells expressing TOP2A failed to express Ki-67 (134). Chromosomal gains at chr17, where TOP2A is harbored, were also found in ACAs, suggesting that it may be an early event in the tumorigenesis of ACT (60).

\section{Clinical implications for the diagnosis and treatment of ACCs}

Considerable advances in the understanding of adrenocortical neoplasia molecular pathology have occurred over the recent years. In spite of this, ACC continues to have a poor prognosis, as they are frequently diagnosed in advanced disease stages and harbor molecular alterations responsible for an aggressive biological behavior. Thus, much efforts are required to identify the main drivers in ACC pathogenesis in order to design the appropriate treatments that are still missing. Nonetheless, recent molecular studies allowed identification of two subsets of ACC tumors with distinctive cell proliferation rates and clinical prognosis $(20,21,70)$. Tumors with worst prognosis depict a high histological grade and present a greater frequency of gene mutations, DNA methylation and a specific miRNA expression profile involving cell cycle and proliferation; more differentiated tumors tend to harbor metabolism instead of cell cyclerelated molecular alterations and have improved clinical outcomes, as evidenced by higher survival rates and lower ENSAT stage (20). There is, however, some overlap between the two tumor categories highlighting the need to pursue the distinctive mechanisms.

The morphological characteristics and the initial molecular studies in ACC supported the hypothesis that proliferation was the most important feature leading to tumor development and dissemination. Genomic analysis has allowed to identify particular gene subsets that are overexpressed while others are under-expressed, whereas more innovative investigations focusing on epigenetic analysis and microRNAs have highlighted additional determinants of tumor biological behavior. Concerning the cell cycle alterations, overexpression of the cell-cyclerelated genes can distinguish the ACC with good and poor prognosis, the last group being the one with an increased expression; in contrast, the adenomas rarely presented those types of alterations and thus those features are possible predictors of malignancy and prognosis (137, 138).

One of the most frequent alterations found in the ACC is LOH in chr11p15, where CDKN1C and IGF2 are localized. IGF2 expression has been demonstrated to be a useful marker for predicting malignancy after ACT surgical removal $(139,140)$. The influence of IGF2 overexpression in the ACC tumorigenesis is well established and reasonably understood. In contrast, CDKN1C under expression is frequently found in ACCs, but its role is not yet fully understood $(73,139)$. Besides its relevance as a diagnostic tool, these alterations have also raised the expectation of being possible treatment targets. Indeed, the use of IGF1-R inhibitors for ACC was tested in several clinical trials but so far failed to improve significantly patients' progression-free survival and overall survival $(141,142,143)$. Subsequently, as IGF1-R is a wellknown mTOR pathway regulator, the combined use of simultaneous IGF1R and mTOR inhibitors to reduce ACC growth was tested. However, the only observable effect was disease stabilization for at least 6 months in $42 \%$ of the patients (144).

TOP2A, whose protein expression is associated with poor overall and disease-free survival $(93,134,135,136)$ is particularly interesting. In ACC, TOP2A seems to be a better proliferation marker even when compared to $\mathrm{Ki}-67$, as some TOP2A-expressing cells fail to express Ki-67 (134). Roca et al. evaluated the TOP2A gene and protein expression in a large series of 98 ACC patients and showed that a high TOP2A expression in ACC tumor is significantly associated with higher response to the combined chemotherapy EDP plus mitotane (EDP$\mathrm{M})$ and with a longer time to tumor progression. These results suggest that TOP $2 \mathrm{~A}$ could also have a potential clinical relevance as a predictor for the EDP-M treatment response (145). TOP2A inhibition has already been tested in in vitro and in clinical trials with some promising results (135). In vitro anti-cancer activity of 14 different agents targeting TOP2A was evaluated. Among these agents the one that demonstrated to have the highest anticancer activity was aclarubicin, and this compound will probably be tested in future clinical trials for the treatment of locally advanced and metastatic ACC (135). Moreover, clinical trials including etoposide and doxorubicin, TOP2 enzyme inhibitors, in combination 
with cisplatin (EDP) used in advanced ACCs resulted in a better progression-free survival when compared to the mitotane and streptozotocin combination (NCT00094497) $(5,146,147)$.

PLK1 regulates multiple steps of cell division and DNA stability/repair. PLK1 expression levels are positively correlated with a poor survival in ACC patients, suggesting PLK1 as a good prognostic marker that could also be a good candidate for targeted therapy $(124,148)$. TKM-080301 is a lipid nanoparticle formulation of a siRNA targeting PLK1. Eight ACC patients (NCT01262235) received two cycles of the treatment and four patients showed a good response in stabilizing disease including a $13 \%$ reduction of tumor size in one patient, thus suggesting that the role of PLK1 inhibition for ACC treatment should be further investigated (149).

The fact that the completed clinical trials produced insufficient outcomes highlights that there is still much to be learned about the molecular pathology of these tumors. Thus, in addition to previous and ongoing clinical trials, other pharmacological targets based on the recent molecular findings related to the cell cycle alterations found in ACC are likely to start being tested in the near future. These include CDK inhibitors, drugs targeting p53 reactivation and CDC25 inhibitors.
The CDK/cyclin complexes have a critical role in the regulation of cell cycle transition that if disrupted can ultimately lead to uncontrolled proliferation. Thus, these are certainly molecular attractive targets for cancer treatment (25). The overexpression of CDK4/6/2 and 1, as well as the overexpression of cyclins involved in the G1-S transition (CCNE1/2) and in the G2-M (CCNB1/2) were recurrently observed in ACC $(53,57,58,59,60$, $68,69,70,71,113)$. CDK inhibitors are being tested for several advanced solid tumors, but there are no registered clinical trials aiming to assess their efficacy in ACCs. Besides, despite the results of the initial clinical trials using CDK inhibitors being disappointing, the recent use of highly selective CDK inhibitors, specifically targeting CDK4 and CDK6, combined with patient stratification, showed a more substantial and promising clinical activity (25). Indeed, a small molecule that is a selective CDK4/6 inhibitor (SHR6390) is in clinical trial for advanced solid tumors, currently in a recruiting phase and thus could represent an opportunity to include patients with ACCs (NCT02684266).

TP53 was recognized as one of ACC driver genes by the pan-genomic studies $(20,21)$. Inactivating mutations were found to be present in $21.3 \%$ of the ACCs $(20,21)$. So, the recovery of p53 'tumor suppressor gene' function,

Table 1 G1/S phase regulators altered in adrenocortical carcinoma (ACC) compared with adrenocortical adenoma (ACA).

\begin{tabular}{|c|c|}
\hline & ACC \\
\hline CDK4 & $\uparrow 64.7 \%$ cases were strongly positive \\
\hline \multirow[t]{2}{*}{ Cyclin E } & $\uparrow 2$-fold \\
\hline & $\uparrow$ Labeling index median of $15 \%$ \\
\hline \multirow[t]{2}{*}{ CCNE1 } & $\uparrow 10.4$-fold \\
\hline & $\uparrow 3.56$-fold \\
\hline \multirow[t]{2}{*}{ Cyclin D1 } & $\uparrow 1.27 \%$ of stained area \\
\hline & $=5.4 \%$ of positive cases \\
\hline \multirow[t]{4}{*}{ p53 } & $\uparrow 59 \%$ of positive cases \\
\hline & $\uparrow 52.4 \%$ of positive cases \\
\hline & $=5.4 \%$ of positive cases \\
\hline & $=7.39 \%$ of stained area \\
\hline$C D K N 1 C$ & $\downarrow 26.3 \%$ of positive cases \\
\hline \multirow[t]{2}{*}{ p21 } & $\uparrow 69.4 \%$ of positive cases \\
\hline & $=1.59 \%$ of stained area \\
\hline \multirow[t]{3}{*}{ p27 } & $\downarrow$ Labeling index of $48.9 \%$ \\
\hline & $\uparrow 94.4 \%$ of positive cases \\
\hline & $\uparrow 9.37 \%$ of stained area \\
\hline \multirow[t]{4}{*}{$C D K N 3$} & $\uparrow 6.84$-fold \\
\hline & $\uparrow 5.28$-fold \\
\hline & $\uparrow$ Higher than 5-fold \\
\hline & $\uparrow 2.69$-fold \\
\hline \multirow[t]{2}{*}{ pRB1 } & $=100 \%$ of positive cases \\
\hline & $\downarrow 13.3 \%$ of cases with abundant staining \\
\hline
\end{tabular}

\begin{tabular}{l}
\hline ACA \\
$\downarrow 13.6 \%$ cases were strongly positive \\
$\downarrow 2$-fold \\
$\downarrow$ Labeling index median of $0 \%$ \\
$\downarrow 10.4$-fold \\
$\downarrow 3.56$-fold \\
$\downarrow 0.1 \%$ of stained area \\
$=0 \%$ of positive cases \\
$\downarrow 0 \%$ of positive cases \\
$\downarrow 11.8 \%$ of positive cases \\
$=0 \%$ of positive cases \\
$=2.99 \%$ of stained area \\
$\uparrow 100.0 \%$ of positive cases \\
$\downarrow 36.4 \%$ of positive cases \\
$=1.25 \%$ of stained area \\
$\uparrow$ Labeling index of $59.4 \%$ \\
$\downarrow 68.8 \%$ of positive cases \\
$\downarrow 3.89 \%$ of stained area \\
$\downarrow 6.84-$ fold \\
$\downarrow 5.28$-fold \\
$\downarrow$ Lower that 5 -fold \\
$\downarrow 2.69$-fold \\
$=100 \%$ of positive cases \\
$\uparrow 73.3 \%$ of cases with abundant staining
\end{tabular}

\begin{tabular}{l}
\hline Ref. \\
\hline$(63)^{\mathrm{a}}$ \\
$(71)^{\mathrm{a}}$ \\
$(67)^{\mathrm{a}}$ \\
$(68)^{\mathrm{b}}$ \\
$(70)^{\mathrm{b}}$ \\
$(45)^{\mathrm{a}}$ \\
$(42)^{\mathrm{a}}$ \\
$(41)^{\mathrm{a}}$ \\
$(153)^{\mathrm{a}}$ \\
$(42)^{\mathrm{a}}$ \\
$(45)^{\mathrm{a}}$ \\
$(62)^{\mathrm{c}}$ \\
$(42)^{\mathrm{a}}$ \\
$(45)^{\mathrm{a}}$ \\
$(83)^{\mathrm{a}}$ \\
$(42)^{\mathrm{a}}$ \\
$(45)^{\mathrm{a}}$ \\
$(68)^{\mathrm{b}}$ \\
$(70)^{\mathrm{b}}$ \\
$(71)^{\mathrm{b}}$ \\
$(113)^{\mathrm{b}}$ \\
$(94)^{\mathrm{a}}$ \\
$(93)^{\mathrm{a}}$
\end{tabular}

ammunohistochemistry analysis; ${ }^{b}$ genome microarray analysis; 'Northern Blot analysis.

$\uparrow$, higher; $\downarrow$, lower; =, similar. 
using MDM2 antagonist (such as RO5503781) and the reactivation of mutant TP53, using PRIMA- ${ }^{\mathrm{MET}}$, already tested for other malignancies (150), also have the potential to be used in ACCs with TP53 inactivated.

Altered expression of CDC25 gene isoforms, repeatedly described in ACCs, could represent a potential treatment target for these tumors $(27,69,70)$. However, despite the fact that several natural and synthetic molecules with distinct structural features targeting CDC25 with good pre-clinical results have been identified $(151,152)$, no registered clinical trials using CDC25 inhibitors for ACC are ongoing.

Finally, in addition to the specific molecules that were identified as potential targets for ACC treatment, there are a few other molecules that despite not having yet been considered for their therapeutic potential, will eventually prove very valuable as new diagnostic and prognostic molecular tools in the near future (Tables 1, 2 and 3).

Table 2 G2/M phase regulators altered in adrenocortical carcinoma (ACC) compared with adrenocortical adenoma (ACA).

\begin{tabular}{|c|c|c|c|}
\hline & ACC & ACA & Ref. \\
\hline \multirow[t]{5}{*}{$C D C 2$} & $\uparrow 7.70$-fold & $\downarrow 7.70$-fold & $(68)^{b}$ \\
\hline & $\uparrow$ Higher than 5-fold & $\downarrow$ Lower that 5-fold & $(71)^{\mathrm{b}}$ \\
\hline & $\uparrow$ & $\downarrow$ & $(69)^{b}$ \\
\hline & $\uparrow 3.76$-fold & $\downarrow 3.76$-fold & $(113)^{\mathrm{b}}$ \\
\hline & $\uparrow 5.85$-fold & $\downarrow 5.85$-fold & $(70)^{\mathrm{b}}$ \\
\hline Cyclin B1 & $\begin{array}{l}\uparrow 43 \% \text { of positive } \\
\text { cases }\end{array}$ & $\begin{array}{l}\downarrow 0 \% \text { of positive } \\
\text { cases }\end{array}$ & $(113)^{a}$ \\
\hline \multirow[t]{4}{*}{ CCNB1 } & $\uparrow$ Higher than 8-fold & $\downarrow$ Lower than 8-fold & $(127)^{b}$ \\
\hline & $\uparrow 7.05$-fold & $\downarrow 7.05$-fold & $(70)^{\mathrm{b}}$ \\
\hline & $\uparrow$ & $\downarrow$ & $(69)^{\mathrm{b}}$ \\
\hline & $\uparrow 2.88$-fold & $\downarrow 2.88$-fold & $(113)^{\mathrm{b}}$ \\
\hline \multirow[t]{4}{*}{ CCNB2 } & $\uparrow 8.88$-fold & $\downarrow$ 8.88-fold & $(68)^{\mathrm{b}}$ \\
\hline & $\uparrow$ Higher than 8-fold & $\downarrow$ Lower than 8-fold & $(127)^{\mathrm{b}}$ \\
\hline & $\uparrow 5.61$-fold & $\downarrow 5.61$-fold & $(70)^{\mathrm{b}}$ \\
\hline & $\uparrow$ Higher than 14 -fold & $\downarrow$ Lower than 14 -fold & $(69)^{\mathrm{b}}$ \\
\hline \multirow[t]{2}{*}{$C D C 25 C$} & $\uparrow 2.22$-fold & $\downarrow 2.22$-fold & $(70)^{\mathrm{b}}$ \\
\hline & $\uparrow$ & $\downarrow$ & $(69)^{\mathrm{b}}$ \\
\hline \multirow[t]{4}{*}{ TOP2A } & $\begin{array}{l}\uparrow \text { Labeling index } \\
\text { mean of } 6.13\end{array}$ & $\begin{array}{l}\downarrow \text { Labeling index } \\
\text { mean of } 0.72\end{array}$ & $(134)^{a}$ \\
\hline & $\begin{array}{l}\uparrow \text { Labeling index } \\
\text { mean of } 37.5\end{array}$ & $\begin{array}{l}\downarrow \text { Labeling index } \\
\text { mean of } 1.4\end{array}$ & $(93)^{\mathrm{a}}$ \\
\hline & $\uparrow$ & $\downarrow$ & $(135)^{a}$ \\
\hline & $\uparrow$ & $\downarrow$ & $(136)^{a}$ \\
\hline \multirow[t]{5}{*}{ TOP2A } & $\uparrow 6.86$-fold & $\downarrow 6.86$-fold & $(68)^{b}$ \\
\hline & $\uparrow$ Higher than 5-fold & $\downarrow$ Lower that 5-fold & $(71)^{\mathrm{b}}$ \\
\hline & $\uparrow 3.54$-fold & $\downarrow 3.54-$ fold & $(70)^{\mathrm{b}}$ \\
\hline & $\uparrow$ Higher than 9-fold & $\downarrow$ Lower that 9-fold & $(69)^{\mathrm{b}}$ \\
\hline & $\uparrow$ & $\downarrow$ & $(135)^{c}$ \\
\hline
\end{tabular}

Immunohistochemistry analysis; ${ }^{b}$ genome microarray analysis; ${ }^{\text {Creal-time }}$ quantitative RT-PCR.

$\uparrow$, higher; $\downarrow$, lower; $=$, similar.
Table 3 Relevant cell cycle regulator to define clinical prognosis.

\begin{tabular}{lll}
\hline Possible prognostic markers & & \multicolumn{1}{c}{ Study } \\
\cline { 1 - 1 } pRB1 loss & & $(91)$ \\
RB1 mutations & & $(20,21)$ \\
chr17p13 $L O H$ & & $(20,21,34,41)$ \\
CCNE1 amplification & $(28)$ \\
Cyclin E overexpression & $(62)$ \\
CDK4 amplification & & $(20,21)$ \\
CDKN2A deletions & $(20,21)$ \\
CCNB2 overexpression & $(27,69,70,127)$ \\
TOP2A overexpression & $(93,134,135,136)$ \\
\hline
\end{tabular}

Results from the pan-genomic studies Zheng et al. and Assié et al. are highlighted $(20,21)$.

\section{Conclusion}

Our aim was to deliver an integrative review of what has been reported regarding cell cycle disruptions in ACC, so that this comprehensive and integrated knowledge could then be used to optimize disease diagnosis and treatment.

The rarity of the ACC represents an important limitation to accomplish a complete molecular characterization of cell cycle alterations. Despite this limitation, collaborative studies focusing in a wide array of molecular pathways have been performed. The results of these studies are summarized in this review, highlighting the complexity of the molecular alterations that may contribute for an aggressive biological behavior in ACC.

The molecular mechanisms underlying the traditional pathological features have already proved to be useful molecular markers for differential diagnosis and tumor stratification and prognosis. In addition, targeting the mechanisms leading to uncontrolled cell proliferation may have a much required potential for ACC treatment. From a clinical perspective, these have already led to the implementation of targeted treatments aiming to be used alone or in combination with the classical adrenolytic drug mitotane. However, we must state that some genomic alterations were analyzed in a non-functional perspective and so up until now their functional impact is most of the times, unknown.

In conclusion, the main goal for the future should be translating what was learned, and summarized in this review, together with the comprehensive information resulting from the pan-genomic studies into better tools to identify and evaluate ACC, as the final objective to develop specific medical therapy personalized for each patient to improve their disease-free intervals and survival. 


\section{Declaration of interest}

The authors declare that there is no conflict of interest that could be perceived as prejudicing the impartiality of this review.

\section{Funding}

Portuguese Foundation for Science and Technology (FCT) funds UMIB (UID/ Multi/00215/2013), I3S (POCI-01-0145-FEDER-007274) and Sofia S Pereira through a PhD fellowship (SFRH/BD/89308/2012).

\section{References}

1 Chagpar R, Siperstein AE \& Berber E. Adrenocortical cancer update. Surgical Clinics of North America 201494 669-687. (https://doi. org/10.1016/j.suc.2014.02.009)

2 Roman S. Adrenocortical carcinoma. Current Opinion in Oncology 2006 18 36-42. (https://doi.org/10.1097/01.cco.0000198976.43992.14)

3 Libe R, Borget I, Ronchi CL, Zaggia B, Kroiss M, Kerkhofs T, Bertherat J, Volante M, Quinkler M, Chabre O et al. Prognostic factors in stage III-IV adrenocortical carcinomas (ACC): an European Network for the Study of Adrenal Tumor (ENSAT) study. Annals of Oncology 201526 2119-2125. (https://doi.org/10.1093/annonc/ mdv329)

4 Else T, Kim AC, Sabolch A, Raymond VM, Kandathil A, Caoili EM, Jolly S, Miller BS, Giordano TJ \& Hammer GD. Adrenocortical carcinoma. Endocrine Reviews 201435 282-326. (https://doi. org/10.1210/er.2013-1029)

5 Fassnacht M, Libe R, Kroiss M \& Allolio B. Adrenocortical carcinoma: a clinician's update. Nature Reviews Endocrinology 20117 323-335. (https://doi.org/10.1038/nrendo.2010.235)

6 Audenet F, Mejean A, Chartier-Kastler E \& Roupret M. Adrenal tumours are more predominant in females regardless of their histological subtype: a review. World Journal of Urology $2013 \mathbf{3 1}$ 1037-1043. (https://doi.org/10.1007/s00345-012-1011-1)

7 Low G, Dhliwayo H \& Lomas DJ. Adrenal neoplasms. Clinical Radiology 201267 988-1000. (https://doi.org/10.1016/j. crad.2012.02.005)

8 Soon PS, McDonald KL, Robinson BG \& Sidhu SB. Molecular markers and the pathogenesis of adrenocortical cancer. Oncologist 200813 548-561. (https://doi.org/10.1634/theoncologist.2007-0243)

9 Lafemina J \& Brennan MF. Adrenocortical carcinoma: past, present, and future. Journal of Surgical Oncology 2012106 586-594. (https:// doi.org/10.1002/jso.23112)

10 Fassnacht M, Arlt W, Bancos I, Dralle H, Newell-Price J, Sahdev A, Tabarin A, Terzolo M, Tsagarakis S \& Dekkers OM. Management of adrenal incidentalomas: European Society of Endocrinology Clinical Practice Guideline in collaboration with the European Network for the Study of Adrenal Tumors. European Journal of Endocrinology 2016 175 G1-G34. (https://doi.org/10.1530/EJE-16-0467)

11 Allolio B \& Fassnacht M. Clinical review: adrenocortical carcinoma: clinical update. Journal of Clinical Endocrinology and Metabolism 2006 91 2027-2037. (https://doi.org/10.1210/jc.2005-2639)

12 Lau SK \& Weiss LM. The Weiss system for evaluating adrenocortical neoplasms: 25 years later. Human Pathology 200940 757-768. (https://doi.org/10.1016/j.humpath.2009.03.010)

13 Tissier F. Classification of adrenal cortical tumors: what limits for the pathological approach? Best Practice and Research: Clinical Endocrinology and Metabolism 201024 877-885. (https://doi. org/10.1016/j.beem.2010.10.011)

14 Wachenfeld C, Beuschlein F, Zwermann O, Mora P, Fassnacht M, Allolio B \& Reincke M. Discerning malignancy in adrenocortical tumors: are molecular markers useful? European Journal of Endocrinology 2001145 335-341. (https://doi.org/10.1530/ eje.0.1450335)
15 Beuschlein F, Weigel J, Saeger W, Kroiss M, Wild V, Daffara F, Libe R, Ardito A, Al Ghuzlan A, Quinkler M et al. Major prognostic role of Ki67 in localized adrenocortical carcinoma after complete resection. Journal of Clinical Endocrinology and Metabolism 2015100 841-849. (https://doi.org/10.1210/jc.2014-3182)

16 Berruti A, Baudin E, Gelderblom H, Haak HR, Porpiglia F, Fassnacht M \& Pentheroudakis G. Adrenal cancer: ESMO Clinical Practice Guidelines for diagnosis, treatment and follow-up. Annals of Oncology 201223 (Supplement 7) vii131-vii138. (https://doi. org/10.1093/annonc/mds231)

17 Fassnacht M, Johanssen S, Quinkler M, Bucsky P, Willenberg HS, Beuschlein F, Terzolo M, Mueller H-H, Hahner S, Allolio B et al. Limited prognostic value of the 2004 International Union Against Cancer staging classification for adrenocortical carcinoma. Cancer 2009115 243-250. (https://doi.org/10.1002/cncr.24030)

18 Abiven G, Coste J, Groussin L, Anract P, Tissier F, Legmann P, Dousset B, Bertagna X \& Bertherat J. Clinical and biological features in the prognosis of adrenocortical cancer: poor outcome of cortisolsecreting tumors in a series of 202 consecutive patients. Journal of Clinical Endocrinology and Metabolism 200691 2650-2655. (https:// doi.org/10.1210/jc.2005-2730)

19 Faillot S \& Assie G. Endocrine tumours: the genomics of adrenocortical tumors. European Journal of Endocrinology 2016174 R249-R265. (https://doi.org/10.1530/EJE-15-1118)

20 Zheng S, Cherniack AD, Dewal N, Moffitt RA, Danilova L, Murray BA, Lerario AM, Else T, Knijnenburg TA, Ciriello G et al. Comprehensive pan-genomic characterization of adrenocortical carcinoma. Cancer Cell 201629 723-736. (https://doi.org/10.1016/j.ccell.2016.04.002)

21 Assie G, Letouze E, Fassnacht M, Jouinot A, Luscap W, Barreau O, Omeiri H, Rodriguez S, Perlemoine K, Rene-Corail F et al. Nature Genetics 201446 607-612. (https://doi.org/10.1038/ng.2953)

22 Cooper GM. The eukaryotic cell cycle. In The Cell: A Molecular Approach, 2nd ed. Sunderland, MA: Sinauer Associates, 2000.

23 Lim S \& Kaldis P. Cdks, cyclins and CKIs: roles beyond cell cycle regulation. Development 2013140 3079-3093. (https://doi. org/10.1242/dev.091744)

24 Park MT \& Lee SJ. Cell cycle and cancer. Journal of Biochemistry and Molecular Biology 200336 60-65. (https://doi.org/10.5483/ BMBRep.2003.36.1.060)

25 Asghar U, Witkiewicz AK, Turner NC \& Knudsen ES. The history and future of targeting cyclin-dependent kinases in cancer therapy. Nature Reviews Drug Discovery 201514 130-146. (https://doi. org/10.1038/nrd4504)

26 Bertoli C, Skotheim JM \& de Bruin RA. Control of cell cycle transcription during G1 and S phases. Nature Reviews Molecular Cell Biology 201314 518-528. (https://doi.org/10.1038/nrm3629)

27 Szabo PM, Tamasi V, Molnar V, Andrasfalvy M, Tombol Z, Farkas R, Kovesdi K, Patocs A, Toth M, Szalai C et al. Meta-analysis of adrenocortical tumour genomics data: novel pathogenic pathways revealed. Oncogene 201029 3163-3172. (https://doi.org/10.1038/ onc.2010.80)

28 el-Deiry WS, Tokino T, Velculescu VE, Levy DB, Parsons R, Trent JM, Lin D, Mercer WE, Kinzler KW \& Vogelstein B. WAF1, a potential mediator of p53 tumor suppression. Cell $1993 \mathbf{7 5} 817-825$. (https:// doi.org/10.1016/0092-8674(93)90500-P)

29 Adams PD, Sellers WR, Sharma SK, Wu AD, Nalin CM \& Kaelin WG Jr. Identification of a cyclin-cdk2 recognition motif present in substrates and p21-like cyclin-dependent kinase inhibitors. Molecular and Cellular Biology 199616 6623-6633. (https://doi.org/10.1128/ MCB.16.12.6623)

30 Hisada M, Garber JE, Fung CY, Fraumeni JF Jr \& Li FP. Multiple primary cancers in families with Li-Fraumeni syndrome. Journal of the National Cancer Institute 199890 606-611. (https://doi.org/10.1093/ jnci/90.8.606)

31 McBride KA, Ballinger ML, Killick E, Kirk J, Tattersall MH, Eeles RA, Thomas DM \& Mitchell G. Li-Fraumeni syndrome: cancer risk 
assessment and clinical management. Nature Reviews Clinical Oncology 201411 260-271. (https://doi.org/10.1038/nrclinonc.2014.41)

32 Waldmann J, Patsalis N, Fendrich V, Langer P, Saeger W, Chaloupka B, Ramaswamy A, Fassnacht M, Bartsch DK \& Slater EP. Clinical impact of TP53 alterations in adrenocortical carcinomas. Langenbecks Archives of Surgery 2012397 209-216. (https://doi. org/10.1007/s00423-011-0868-6)

33 Libe R, Groussin L, Tissier F, Elie C, Rene-Corail F, Fratticci A, Jullian E, Beck-Peccoz P, Bertagna X, Gicquel C et al. Somatic TP53 mutations are relatively rare among adrenocortical cancers with the frequent 17p13 loss of heterozygosity. Clinical Cancer Research 2007 13 844-850. (https://doi.org/10.1158/1078-0432.CCR-06-2085)

34 Barzon L, Chilosi M, Fallo F, Martignoni G, Montagna L, Palu G \& Boscaro M. Molecular analysis of CDKN1C and TP53 in sporadic adrenal tumors. European Journal of Endocrinology 2001145 207-212. (https://doi.org/10.1530/eje.0.1450207)

35 Herrmann LJ, Heinze B, Fassnacht M, Willenberg HS, Quinkler M, Reisch N, Zink M, Allolio B \& Hahner S. TP53 germline mutations in adult patients with adrenocortical carcinoma. Journal of Clinical Endocrinology and Metabolism 201297 E476-E485. (https://doi. org/10.1210/jc.2011-1982)

36 Ohgaki H, Kleihues P \& Heitz PU. p53 mutations in sporadic adrenocortical tumors. International Journal of Cancer $1993 \mathbf{5 4}$ 408-410. (https://doi.org/10.1002/ijc.2910540310)

37 Wasserman JD, Novokmet A, Eichler-Jonsson C, Ribeiro RC, Rodriguez-Galindo C, Zambetti GP \& Malkin D. Prevalence and functional consequence of TP53 mutations in pediatric adrenocortical carcinoma: a children's oncology group study. Journal of Clinical Oncology 201533 602-609. (https://doi.org/10.1200/ JCO.2013.52.6863)

38 Wagner J, Portwine C, Rabin K, Leclerc JM, Narod SA \& Malkin D. High frequency of germline p53 mutations in childhood adrenocortical cancer. Journal of the National Cancer Institute $1994 \mathbf{8 6}$ 1707-1710. (https://doi.org/10.1093/jnci/86.22.1707)

39 Varley JM, McGown G, Thorncroft M, James LA, Margison GP, Forster G, Evans DG, Harris M, Kelsey AM \& Birch JM. Are there lowpenetrance TP53 Alleles? evidence from childhood adrenocortical tumors. American Journal of Human Genetics 199965 995-1006. (https://doi.org/10.1086/302575)

40 Ragazzon B, Libe R, Gaujoux S, Assie G, Fratticci A, Launay P, Clauser E, Bertagna X, Tissier F, de Reynies A et al. Transcriptome analysis reveals that p53 and \{beta\}-catenin alterations occur in a group of aggressive adrenocortical cancers. Cancer Research 201070 8276-8281. (https://doi.org/10.1158/0008-5472.CAN-10-2014)

41 Arola J, Salmenkivi K, Liu J, Kahri AI \& Heikkila P. p53 and Ki67 in adrenocortical tumors. Endocrine Research 200026 861-865. (https:// doi.org/10.3109/07435800009048609)

42 Stojadinovic A, Brennan MF, Hoos A, Omeroglu A, Leung DH, Dudas ME, Nissan A, Cordon-Cardo C \& Ghossein RA. Adrenocortical adenoma and carcinoma: histopathological and molecular comparative analysis. Modern Pathology 200316 742-751. (https://doi.org/10.1097/01.MP.0000081730.72305.81)

43 McNicol AM, Struthers AL, Nolan CE, Hermans J \& Haak HR. Proliferation in adrenocortical tumors: correlation with clinical outcome and p53 status. Endocrine Pathology 19978 29-36. (https:// doi.org/10.1007/BF02739705)

44 Reincke M, Karl M, Travis WH, Mastorakos G, Allolio B, Linehan HM \& Chrousos GP. p53 mutations in human adrenocortical neoplasms: immunohistochemical and molecular studies. Journal of Clinical Endocrinology and Metabolism 199478 790-794. (https://doi. org/10.1210/jcem.78.3.8126158)

45 Pereira SS, Morais T, Costa MM, Monteiro MP \& Pignatelli D. The emerging role of the molecular marker p27 in the differential diagnosis of adrenocortical tumors. Endocrine Connections 20132 137-145. (https://doi.org/10.1530/EC-13-0025)
46 Sbragia L, Oliveira-Filho AG, Vassallo J, Pinto GA, Guerra-Junior G $\&$ Bustorff-Silva J. Adrenocortical tumors in Brazilian children: immunohistochemical markers and prognostic factors. Archives of Pathology and Laboratory Medicine 2005129 1127-1131.

47 Moll UM \& Petrenko O. The MDM2-p53 interaction. Molecular Cancer Research 20031 1001-1008.

48 Shi D \& Gu W. Dual roles of MDM2 in the regulation of p53: ubiquitination dependent and ubiquitination independent mechanisms of MDM2 repression of p53 activity. Genes and Cancer 20123 240-248. (https://doi.org/10.1177/1947601912455199)

49 Tao W \& Levine AJ. P19(ARF) stabilizes p53 by blocking nucleocytoplasmic shuttling of Mdm2. PNAS 199996 6937-6941. (https:// doi.org/10.1073/pnas.96.12.6937)

50 De Martino MC, Al Ghuzlan A, Aubert S, Assie G, Scoazec JY, Leboulleux S, Do Cao C, Libe R, Nozieres C, Lombes M et al. Molecular screening for a personalized treatment approach in advanced adrenocortical cancer. Journal of Clinical Endocrinology and Metabolism 201398 4080-4088. (https://doi.org/10.1210/jc.20132165)

51 Ross JS, Wang K, Rand JV, Gay L, Presta MJ, Sheehan CE, Ali SM, Elvin JA, Labrecque E, Hiemstra C et al. Next-generation sequencing of adrenocortical carcinoma reveals new routes to targeted therapies. Journal of Clinical Pathology 201467 968-973. (https://doi. org/10.1136/jclinpath-2014-202514)

52 Letouze E, Rosati R, Komechen H, Doghman M, Marisa L, Fluck C, de Krijger RR, van Noesel MM, Mas JC, Pianovski MA et al. SNP array profiling of childhood adrenocortical tumors reveals distinct pathways of tumorigenesis and highlights candidate driver genes. Journal of Clinical Endocrinology and Metabolism 201297 E1284-E1293. (https://doi.org/10.1210/jc.2012-1184)

53 Stephan EA, Chung TH, Grant CS, Kim S, Von Hoff DD, Trent JM \& Demeure MJ. Adrenocortical carcinoma survival rates correlated to genomic copy number variants. Molecular Cancer Therapeutics $2008 \mathbf{7}$ 425-431. (https://doi.org/10.1158/1535-7163.MCT-07-0267)

54 Zajac-Kaye M. Myc oncogene: a key component in cell cycle regulation and its implication for lung cancer. Lung Cancer 2001 34 (Supplement 2) S43-S46. (https://doi.org/10.1016/S01695002(01)00343-9)

55 Bartek J, Bartkova J \& Lukas J. The retinoblastoma protein pathway and the restriction point. Current Opinion in Cell Biology 19968 805-814. (https://doi.org/10.1016/S0955-0674(96)80081-0)

56 Sherr CJ. The Pezcoller lecture: cancer cell cycles revisited. Cancer Research 200060 3689-3695.

57 Barreau O, de Reynies A, Wilmot-Roussel H, Guillaud-Bataille M, Auzan C, Rene-Corail F, Tissier F, Dousset B, Bertagna X, Bertherat J et al. Clinical and pathophysiological implications of chromosomal alterations in adrenocortical tumors: an integrated genomic approach. Journal of Clinical Endocrinology and Metabolism 201297 E301-E311. (https://doi.org/10.1210/jc.2011-1588)

58 Zhao J, Roth J, Bode-Lesniewska B, Pfaltz M, Heitz PU \& Komminoth P. Combined comparative genomic hybridization and genomic microarray for detection of gene amplifications in pulmonary artery intimal sarcomas and adrenocortical tumors. Genes, Chromosomes and Cancer 200234 48-57. (https://doi. org/10.1002/gcc.10035)

59 Dohna M, Reincke M, Mincheva A, Allolio B, Solinas-Toldo S \& Lichter P. Adrenocortical carcinoma is characterized by a high frequency of chromosomal gains and high-level amplifications. Genes, Chromosomes and Cancer 200028 145-152. (https:// doi.org/10.1002/(SICI)1098-2264(200006)28:2<145::AIDGCC3>3.0.CO;2-7)

60 Zhao J, Speel EJ, Muletta-Feurer S, Rutimann K, Saremaslani P, Roth J, Heitz PU \& Komminoth P. Analysis of genomic alterations in sporadic adrenocortical lesions. Gain of chromosome 17 is an early event in adrenocortical tumorigenesis. American Journal of 
Pathology 1999155 1039-1045. (https://doi.org/10.1016/S00029440(10)65205-4)

61 Ragazzon B, Assie G \& Bertherat J. Transcriptome analysis of adrenocortical cancers: from molecular classification to the identification of new treatments. Endocrine-Related Cancer 201118 R15-R27. (https://doi.org/10.1530/ERC-10-0290)

62 Bourcigaux N, Gaston V, Logie A, Bertagna X, Le Bouc Y \& Gicquel C. High expression of cyclin E and G1 CDK and loss of function of p57KIP2 are involved in proliferation of malignant sporadic adrenocortical tumors. Journal of Clinical Endocrinology and Metabolism 200085 322-330. (https://doi.org/10.1210/ jcem.85.1.6303)

63 Schmitt A, Saremaslani P, Schmid S, Rousson V, Montani M, Schmid DM, Heitz PU, Komminoth P \& Perren A. IGFII and MIB1 immunohistochemistry is helpful for the differentiation of benign from malignant adrenocortical tumours. Histopathology 200649 298-307. (https://doi.org/10.1111/j.1365-2559.2006.02505.x)

64 Hwang HC \& Clurman BE. Cyclin E in normal and neoplastic cell cycles. Oncogene 200524 2776-2786. (https://doi.org/10.1038/ sj.onc.1208613)

65 Caldon CE \& Musgrove EA. Distinct and redundant functions of cyclin E1 and cyclin E2 in development and cancer. Cell Division 20105 2. (https://doi.org/10.1186/1747-1028-5-2)

66 Berrebi D, Leclerc J, Schleiermacher G, Zaccaria I, Boccon-Gibod L, Fabre M, Jaubert F, El Ghoneimi A, Jeanpierre C \& Peuchmaur M. High cyclin E staining index in blastemal, stromal or epithelial cells is correlated with tumor aggressiveness in patients with nephroblastoma. PLoS ONE 20083 e2216. (https://doi.org/10.1371/ journal.pone.0002216)

67 Tissier F, Louvel A, Grabar S, Hagnere AM, Bertherat J, VacherLavenu MC, Dousset B, Chapuis Y, Bertagna X \& Gicquel C. Cyclin E correlates with malignancy and adverse prognosis in adrenocortical tumors. European Journal of Endocrinology 2004150 809-817. (https:// doi.org/10.1530/eje.0.1500809)

68 Giordano TJ, Thomas DG, Kuick R, Lizyness M, Misek DE, Smith AL, Sanders D, Aljundi RT, Gauger PG, Thompson NW et al. Distinct transcriptional profiles of adrenocortical tumors uncovered by DNA microarray analysis. American Journal of Pathology 2003162 521-531. (https://doi.org/10.1016/S0002-9440(10)63846-1)

69 Tombol Z, Szabo PM, Molnar V, Wiener Z, Tolgyesi G, Horanyi J, Riesz P, Reismann P, Patocs A, Liko I et al. Integrative molecular bioinformatics study of human adrenocortical tumors: microRNA, tissue-specific target prediction, and pathway analysis. EndocrineRelated Cancer 200916 895-906. (https://doi.org/10.1677/ERC-090096)

70 de Reynies A, Assie G, Rickman DS, Tissier F, Groussin L, ReneCorail F, Dousset B, Bertagna X, Clauser E \& Bertherat J. Gene expression profiling reveals a new classification of adrenocortical tumors and identifies molecular predictors of malignancy and survival. Journal of Clinical Oncology 200927 1108-1115. (https://doi. org/10.1200/JCO.2008.18.5678)

71 Giordano TJ, Kuick R, Else T, Gauger PG, Vinco M, Bauersfeld J, Sanders D, Thomas DG, Doherty G \& Hammer G. Molecular classification and prognostication of adrenocortical tumors by transcriptome profiling. Clinical Cancer Research 200915 668-676. (https://doi.org/10.1158/1078-0432.CCR-08-1067)

72 Borriello A, Caldarelli I, Bencivenga D, Criscuolo M, Cucciolla V, Tramontano A, Oliva A, Perrotta S \& Della Ragione F. p57(Kip2) and cancer: time for a critical appraisal. Molecular Cancer Research 20119 1269-1284. (https://doi.org/10.1158/1541-7786.MCR-11-0220)

73 Liu J, Kahri AI, Heikkila P \& Voutilainen R. Ribonucleic acid expression of the clustered imprinted genes, p57KIP2, insulin-like growth factor II, and H19, in adrenal tumors and cultured adrenal cells. Journal of Clinical Endocrinology and Metabolism 199782 1766-1771. (https://doi.org/10.1210/jcem.82.6.3968)
74 Gicquel C, Raffin-Sanson ML, Gaston V, Bertagna X, Plouin PF, Schlumberger M, Louvel A, Luton JP \& Le Bouc Y. Structural and functional abnormalities at 11 p15 are associated with the malignant phenotype in sporadic adrenocortical tumors: study on a series of 82 tumors. Journal of Clinical Endocrinology and Metabolism 199782 2559-2565. (https://doi.org/10.1210/jcem.82.8.4170)

75 Sidhu S, Gicquel C, Bambach CP, Campbell P, Magarey C, Robinson BG \& Delbridge LW. Clinical and molecular aspects of adrenocortical tumourigenesis. ANZ Journal of Surgery $2003 \mathbf{7 3}$ 727-738. (https://doi.org/10.1046/j.1445-2197.2003.02746.x)

76 West AN, Neale GA, Pounds S, Figueredo BC, Rodriguez Galindo C, Pianovski MA, Oliveira Filho AG, Malkin D, Lalli E, Ribeiro R et al. Gene expression profiling of childhood adrenocortical tumors. Cancer Research 200767 600-608. (https://doi.org/10.1158/00085472.CAN-06-3767)

77 Dominguez-Brauer C, Brauer PM, Chen YJ, Pimkina J \& Raychaudhuri P. Tumor suppression by ARF: gatekeeper and caretaker. Cell Cycle 20109 86-89. (https://doi.org/10.4161/ cc.9.1.10350)

78 Pilon C, Pistorello M, Moscon A, Altavilla G, Pagotto U, Boscaro M \& Fallo F. Inactivation of the p16 tumor suppressor gene in adrenocortical tumors. Journal of Clinical Endocrinology and Metabolism 199984 2776-2779. (https://doi.org/10.1210/ jcem.84.8.5877)

79 Lloyd RV, Erickson LA, Jin L, Kulig E, Qian X, Cheville JC \& Scheithauer BW. p27kip1: a multifunctional cyclin-dependent kinase inhibitor with prognostic significance in human cancers. American Journal of Pathology 1999154 313-323. (https:/doi.org/10.1016/ S0002-9440(10)65277-7)

80 Warfel NA \& El-Deiry WS. p21WAF1 and tumourigenesis: 20 years after. Current Opinion in Oncology 201325 52-58. (https://doi. org/10.1097/CCO.0b013e32835b639e)

81 Nickeleit I, Zender S, Kossatz U \& Malek NP. p27kip1: a target for tumor therapies? Cell Division 20072 13. (https://doi. org/10.1186/1747-1028-2-13)

82 Babinska A, Sworczak K, Wisniewski P, Nalecz A \& Jaskiewicz K. The role of immunohistochemistry in histopathological diagnostics of clinically 'silent' incidentally detected adrenal masses. Experimental and Clinical Endocrinology and Diabetes 2008116 246-251. (https:// doi.org/10.1055/s-2007-993164)

83 Nakazumi H, Sasano H, Iino K, Ohashi Y \& Orikasa S. Expression of cell cycle inhibitor p27 and Ki-67 in human adrenocortical neoplasms. Modern Pathology 199811 1165-1170.

84 Giacinti C \& Giordano A. RB and cell cycle progression. Oncogene 200625 5220-5227. (https://doi.org/10.1038/sj.onc.1209615)

85 Takaki T, Fukasawa K, Suzuki-Takahashi I \& Hirai H. Cdk-mediated phosphorylation of pRB regulates HDAC binding in vitro. Biochemical and Biophysical Research Communications 2004316 252-255. (https:// doi.org/10.1016/j.bbrc.2004.02.044)

86 Sun A, Bagella L, Tutton S, Romano G \& Giordano A. From G0 to S phase: a view of the roles played by the retinoblastoma $(\mathrm{Rb})$ family members in the Rb-E2F pathway. Journal of Cellular Biochemistry 2007 102 1400-1404. (https://doi.org/10.1002/jcb.21609)

87 Rhodes DR, Kalyana-Sundaram S, Mahavisno V, Barrette TR, Ghosh D \& Chinnaiyan AM. Mining for regulatory programs in the cancer transcriptome. Nature Genetics 200537 579-583. (https://doi. org/10.1038/ng1578)

88 Sidhu S, Marsh DJ, Theodosopoulos G, Philips J, Bambach CP, Campbell P, Magarey CJ, Russell CF, Schulte KM, Roher HD et al. Comparative genomic hybridization analysis of adrenocortical tumors. Journal of Clinical Endocrinology and Metabolism 200287 3467-3474. (https://doi.org/10.1210/jcem.87.7.8697)

89 Kjellman M, Kallioniemi OP, Karhu R, Hoog A, Farnebo LO, Auer G, Larsson C \& Backdahl M. Genetic aberrations in adrenocortical tumors detected using comparative genomic hybridization correlate 
with tumor size and malignancy. Cancer Reseacrh 199656 4219-4223.

90 Di Fiore R, D'Anneo A, Tesoriere G \& Vento R. RB1 in cancer: different mechanisms of RB1 inactivation and alterations of $\mathrm{pRb}$ pathway in tumorigenesis. Journal of Cellular Physiology 2013228 1676-1687. (https://doi.org/10.1002/jcp.24329)

91 Ragazzon B, Libe R, Assie G, Tissier F, Barreau O, Houdayer C, Perlemoine K, Audebourg A, Clauser E, Rene-Corail F et al. Massarray screening of frequent mutations in cancers reveals RB1 alterations in aggressive adrenocortical carcinomas. European Journal of Endocrinology 2014170 385-391. (https://doi.org/10.1530/EJE-130778)

92 de Fraipont F, El Atifi M, Cherradi N, Le Moigne G, Defaye G, Houlgatte R, Bertherat J, Bertagna X, Plouin PF, Baudin E et al. Gene expression profiling of human adrenocortical tumors using complementary deoxyribonucleic acid microarrays identifies several candidate genes as markers of malignancy. Journal of Clinical Endocrinology and Metabolism 200590 1819-1829. (https://doi. org/10.1210/jc.2004-1075)

93 Gupta D, Shidham V, Holden J \& Layfield L. Value of topoisomerase II alpha, MIB-1, p53, E-cadherin, retinoblastoma gene protein product, and HER-2/neu immunohistochemical expression for the prediction of biologic behavior in adrenocortical neoplasms. Applied Immunohistochemistry and Molecular Morphology 20019 215-221. (https://doi.org/10.1097/00129039-200103000-00016)

94 Vargas MP, Vargas HI, Kleiner DE \& Merino MJ. Adrenocortical neoplasms: role of prognostic markers MIB-1, P53, and RB. American Journal of Surgical Pathology 199721 556-562. (https://doi. org/10.1097/00000478-199705000-00008)

95 Dang CV. MYC, metabolism, cell growth, and tumorigenesis. Cold Spring Harbor Perspectives in Medicine 20133 a014217. (https://doi. org/10.1101/cshperspect.a014217)

96 Nesbit CE, Tersak JM \& Prochownik EV. MYC oncogenes and human neoplastic disease. Oncogene 199918 3004-3016. (https://doi. org/10.1038/sj.onc.1202746)

97 Szabo PM, Racz K \& Igaz P. Underexpression of C-myc in adrenocortical cancer: a major pathogenic event? Hormone and Metabolic Research 201143 297-299. (https://doi. org/10.1055/s-0031-1273762)

98 Liu J, Voutilainen R, Kahri AI \& Heikkila P. Expression patterns of the c-myc gene in adrenocortical tumors and pheochromocytomas. Journal of Endocrinology 1997152 175-181. (https://doi.org/10.1677/ joe.0.1520175)

99 Suzuki T, Sasano H, Nisikawa T, Rhame J, Wilkinson DS \& Nagura H. Discerning malignancy in human adrenocortical neoplasms: utility of DNA flow cytometry and immunohistochemistry. Modern Pathology 19925 224-231.

100 DiPaola RS. To arrest or not to G(2)-M Cell-cycle arrest: commentary re: A. K. Tyagi et al., Silibinin strongly synergizes human prostate carcinoma DU145 cells to doxorubicin-induced growth inhibition, G(2)-M arrest, and apoptosis. Clin. cancer res., 8: 3512-3519, 2002. Clinical Cancer Research 20028 3311-3314.

101 Kaldis P \& Aleem E. Cell cycle sibling rivalry: Cdc2 vs. Cdk2. Cell Cycle 20054 1491-1494. (https://doi.org/10.4161/cc.4.11.2124)

102 Nakayama Y \& Yamaguchi N. Role of cyclin B1 levels in DNA damage and DNA damage-induced senescence. International Review of Cell and Molecular Biology 2013305 303-337. (https://doi.org/10.1016/B9780-12-407695-2.00007-X)

103 Desai D, Wessling HC, Fisher RP \& Morgan DO. Effects of phosphorylation by CAK on cyclin binding by CDC2 and CDK2 Molecular and Cellular Biology 199515 345-350. (https://doi. org/10.1128/MCB.15.1.345)

104 Schmit TL \& Ahmad N. Regulation of mitosis via mitotic kinases: new opportunities for cancer management. Molecular Cancer Therapeutics 20076 1920-1931. (https://doi.org/10.1158/1535-7163. MCT-06-0781)
105 Porter LA \& Donoghue DJ. Cyclin B1 and CDK1: nuclear localization and upstream regulators. Progress in Cell Cycle Research 20035 335-347.

106 Lindqvist A, Rodriguez-Bravo V \& Medema RH. The decision to enter mitosis: feedback and redundancy in the mitotic entry network. Journal of Cell Biology 2009185 193-202. (https://doi.org/10.1083/ jcb.200812045)

107 Toyoshima-Morimoto F, Taniguchi E \& Nishida E. Plk1 promotes nuclear translocation of human Cdc25C during prophase. EMBO Reports 20023 341-348. (https://doi.org/10.1093/embo-reports/ kvf069)

108 Frazer C \& Young PG. Phosphorylation Mediated Regulation of Cdc25 Activity, Localization and Stability, Protein Phosphorylation in Human Health. Cai Huang 2012, IntechOpen (https://doi. org/10.5772/48315)

109 Karlsson-Rosenthal C \& Millar JB. Cdc25: mechanisms of checkpoint inhibition and recovery. Trends in Cell Biology 200616 285-292. (https://doi.org/10.1016/j.tcb.2006.04.002)

110 Abraham RT. Cell cycle checkpoint signaling through the ATM and ATR kinases. Genes and Development 200115 2177-2196. (https://doi. org/10.1101/gad.914401)

111 Goh G, Scholl UI, Healy JM, Choi M, Prasad ML, Nelson-Williams C, Kunstman JW, Korah R, Suttorp AC, Dietrich D et al. Recurrent activating mutation in PRKACA in cortisol-producing adrenal tumors. Nature Genetics 201446 613-617. (https://doi.org/10.1038/ ng.2956)

112 Lai F, Godley LA, Joslin J, Fernald AA, Liu J, Espinosa R 3rd, Zhao N, Pamintuan L, Till BG, Larson RA et al. Transcript map and comparative analysis of the $1.5-\mathrm{Mb}$ commonly deleted segment of human $5 q 31$ in malignant myeloid diseases with a del(5q). Genomics 200171 235-245. (https://doi.org/10.1006/geno.2000.6414)

113 Soon PS, Gill AJ, Benn DE, Clarkson A, Robinson BG, McDonald KL \& Sidhu SB. Microarray gene expression and immunohistochemistry analyses of adrenocortical tumors identify IGF2 and Ki-67 as useful in differentiating carcinomas from adenomas. Endocrine-Related Cancer 200916 573-583. (https://doi. org/10.1677/ERC-08-0237)

114 Tokumitsu Y, Mori M, Tanaka S, Akazawa K, Nakano S \& Niho Y. Prognostic significance of polo-like kinase expression in esophageal carcinoma. International Journal of Oncology 199915 687-692.

115 Takahashi T, Sano B, Nagata T, Kato H, Sugiyama Y, Kunieda K, Kimura M, Okano Y \& Saji S. Polo-like kinase 1 (PLK1) is overexpressed in primary colorectal cancers. Cancer Science 200394 148-152. (https://doi.org/10.1111/j.1349-7006.2003.tb01411.x)

116 Knecht R, Elez R, Oechler M, Solbach C, von Ilberg C \& Strebhardt K. Prognostic significance of polo-like kinase (PLK) expression in squamous cell carcinomas of the head and neck. Cancer Research 199959 2794-2797.

117 Wolf G, Elez R, Doermer A, Holtrich U, Ackermann H, Stutte HJ Altmannsberger HM, Rubsamen-Waigmann H \& Strebhardt K. Prognostic significance of polo-like kinase (PLK) expression in non-small cell lung cancer. Oncogene 199714 543-549. (https://doi. org/10.1038/sj.onc.1200862)

118 Weichert W, Denkert C, Schmidt M, Gekeler V, Wolf G, Kobel M, Dietel M \& Hauptmann S. Polo-like kinase isoform expression is a prognostic factor in ovarian carcinoma. British Journal of Cancer 2004 90 815-821. (https://doi.org/10.1038/sj.bjc.6601610)

119 Ito Y, Miyoshi E, Sasaki N, Kakudo K, Yoshida H, Tomoda C, Uruno T, Takamura Y, Miya A, Kobayashi K et al. Polo-like kinase 1 overexpression is an early event in the progression of papillary carcinoma. British Journal of Cancer 200490 414-418. (https://doi. org/10.1038/sj.bjc.6601540)

120 Mross K, Frost A, Steinbild S, Hedbom S, Rentschler J, Kaiser R, Rouyrre N, Trommeshauser D, Hoesl CE \& Munzert G. Phase I dose escalation and pharmacokinetic study of BI 2536, a novel Polo-like kinase 1 inhibitor, in patients with advanced solid tumors. Journal 
of Clinical Oncology 200826 5511-5517. (https://doi.org/10.1200/ JCO.2008.16.1547)

121 McInnes C, Mazumdar A, Mezna M, Meades C, Midgley C, Scaerou F, Carpenter L, Mackenzie M, Taylor P, Walkinshaw M et al. Inhibitors of Polo-like kinase reveal roles in spindle-pole maintenance. Nature Chemical Biology 20062 608-617. (https://doi.org/10.1038/ nchembio825)

122 Nogawa M, Yuasa T, Kimura S, Tanaka M, Kuroda J, Sato K, Yokota A, Segawa H, Toda Y, Kageyama S et al. Intravesical administration of small interfering RNA targeting PLK-1 successfully prevents the growth of bladder cancer. Journal of Clinical Investigation 2005115 978-985. (https://doi.org/10.1172/JCI23043)

123 Linnehan CK, Coan KE, Kim J-H, Wandoloski M, Dastrup E, Rogers E, DelGiorno K, Gonzales P, Barrett MT \& Von Hoff D. Inhibition of Polo-like kinase 1 as a strategy in the treatment of adrenocortical carcinoma. Cancer Research 201272 978-978. (https://doi. org/10.1158/1538-7445.AM2012-978)

124 Bussey KJ, Bapat A, Linnehan C, Wandoloski M, Dastrup E, Rogers E, Gonzales P \& Demeure MJ. Targeting polo-like kinase 1, a regulator of p53, in the treatment of adrenocortical carcinoma. Clinical and Translational Medicine 20165 1. (https://doi.org/10.1186/s40169-0150080-3)

125 Nieduszynski CA, Murray J \& Carrington M. Whole-genome analysis of animal A- and B-type cyclins. Genome Biology 2002 3 RESEARCH0070. (https://doi.org/10.1186/gb-2002-3-12research0070)

126 Lozano JC, Perret E, Schatt P, Arnould C, Peaucellier G \& Picard A. Molecular cloning, gene localization, and structure of human cyclin B3. Biochemical and Biophysical Research Communications 2002291 406-413. (https://doi.org/10.1006/bbrc.2002.6458)

127 Fernandez-Ranvier GG, Weng J, Yeh RF, Khanafshar E, Suh I, Barker C, Duh QY, Clark OH \& Kebebew E. Identification of biomarkers of adrenocortical carcinoma using genomewide gene expression profiling. Archives of Surgery 2008143 841-846; discussion 846. (https://doi.org/10.1001/archsurg.143.9.841)

128 Liu F, Stanton JJ, Wu Z \& Piwnica-Worms H. The human Myt1 kinase preferentially phosphorylates Cdc2 on threonine 14 and localizes to the endoplasmic reticulum and Golgi complex. Molecular and Cellular Biology 199717 571-583. (https://doi.org/10.1128/MCB.17.2.571)

129 Liu F, Rothblum-Oviatt C, Ryan CE \& Piwnica-Worms H. Overproduction of human Myt1 kinase induces a G2 cell cycle delay by interfering with the intracellular trafficking of Cdc2-cyclin B1 complexes. Molecular and Cellular Biology 199919 5113-5123. (https://doi.org/10.1128/MCB.19.7.5113)

130 Baldin V \& Ducommun B. Subcellular localisation of human wee1 kinase is regulated during the cell cycle. Journal of Cell Science 1995 $1082425-2432$.

131 Nitiss JL. DNA topoisomerase II and its growing repertoire of biological functions. Nature Reviews Cancer 20099 327-337. (https:// doi.org/10.1038/nrc2608)

132 Wang JC. DNA topoisomerases. Annual Review of Biochemistry 1996 65 635-692. (https://doi.org/10.1146/annurev.bi.65.070196.003223)

133 Wendorff TJ, Schmidt BH, Heslop P, Austin CA \& Berger JM. The structure of DNA-bound human topoisomerase II alpha: conformational mechanisms for coordinating inter-subunit interactions with DNA cleavage. Journal of Molecular Biology 2012424 109-124. (https://doi.org/10.1016/j.jmb.2012.07.014)

134 Iino K, Sasano H, Yabuki N, Oki Y, Kikuchi A, Yoshimi T \& Nagura H. DNA topoisomerase II alpha and Ki-67 in human adrenocortical neoplasms: a possible marker of differentiation between adenomas and carcinomas. Modern Pathology 199710 901-907.

135 Jain M, Zhang L, He M, Zhang YQ, Shen M \& Kebebew E. TOP2A is overexpressed and is a therapeutic target for adrenocortical carcinoma. Endocrine-Related Cancer 201320 361-370. (https://doi. org/10.1530/ERC-12-0403)
136 Ip JC, Pang TC, Glover AR, Soon P, Zhao JT, Clarke S, Robinson BG, Gill AJ \& Sidhu SB. Immunohistochemical validation of overexpressed genes identified by global expression microarrays in adrenocortical carcinoma reveals potential predictive and prognostic biomarkers. Oncologist 201520 247-256. (https://doi.org/10.1634/ theoncologist.2014-0392)

137 Angelousi A, Dimitriadis GK, Zografos G, Nolting S, Kaltsas G \& Grossman A. Molecular targeted therapies in adrenal, pituitary and parathyroid malignancies. Endocrine-Related Cancer 201724 R239-R259. (https://doi.org/10.1530/ERC-16-0542)

138 Assie G, Jouinot A \& Bertherat J. The 'omics' of adrenocortical tumours for personalized medicine. Nature Reviews Endocrinology 2014 10 215-228. (https://doi.org/10.1038/nrendo.2013.272)

139 Libe R, Fratticci A \& Bertherat J. Adrenocortical cancer: pathophysiology and clinical management. Endocrine-Related Cancer 200714 13-28. (https://doi.org/10.1677/erc.1.01130)

140 Gicquel C, Bertagna X, Gaston V, Coste J, Louvel A, Baudin E, Bertherat J, Chapuis Y, Duclos JM, Schlumberger M et al. Molecular markers and long-term recurrences in a large cohort of patients with sporadic adrenocortical tumors. Cancer Research 200161 6762-6767.

141 Cohen BD, Baker DA, Soderstrom C, Tkalcevic G, Rossi AM, Miller PE, Tengowski MW, Wang F, Gualberto A, Beebe JS et al. Combination therapy enhances the inhibition of tumor growth with the fully human anti-type 1 insulin-like growth factor receptor monoclonal antibody CP-751,871. Clinical Cancer Research 200511 2063-2073. (https://doi.org/10.1158/1078-0432.CCR-04-1070)

142 Haluska P, Worden F, Olmos D, Yin D, Schteingart D, Batzel GN, Paccagnella ML, de Bono JS, Gualberto A \& Hammer GD. Safety, tolerability, and pharmacokinetics of the anti-IGF-1R monoclonal antibody figitumumab in patients with refractory adrenocortical carcinoma. Cancer Chemotherapy and Pharmacology 201065 765-773. (https://doi.org/10.1007/s00280-009-1083-9)

143 Fassnacht M, Berruti A, Baudin E, Demeure MJ, Gilbert J, Haak H, Kroiss M, Quinn DI, Hesseltine E, Ronchi CL et al. Linsitinib (OSI906) versus placebo for patients with locally advanced or metastatic adrenocortical carcinoma: a double-blind, randomised, phase 3 study. Lancet Oncology 201516 426-435. (https://doi.org/10.1016/ S1470-2045(15)70081-1)

144 Naing A, Kurzrock R, Burger A, Gupta S, Lei X, Busaidy N, Hong D, Chen HX, Doyle LA, Heilbrun LK et al. Phase I trial of cixutumumab combined with temsirolimus in patients with advanced cancer. Clinical Cancer Research 201117 6052-6060. (https://doi. org/10.1158/1078-0432.CCR-10-2979)

145 Roca E, Berruti A, Sbiera S, Rapa I, Oneda E, Sperone P, Ronchi CL, Ferrari L, Grisanti S, Germano A et al. Topoisomerase 2alpha and thymidylate synthase expression in adrenocortical cancer. EndocrineRelated Cancer 201724 299-307. (https://doi.org/10.1530/ERC-170095)

146 Libe R. Adrenocortical carcinoma (ACC): diagnosis, prognosis, and treatment. Frontiers in Cell and Developmental Biology 2015345. (https://doi.org/10.3389/fcell.2015.00045)

147 Fassnacht M, Terzolo M, Allolio B, Baudin E, Haak H, Berruti A, Welin S, Schade-Brittinger C, Lacroix A, Jarzab B et al. Combination chemotherapy in advanced adrenocortical carcinoma. New England Journal of Medicine 2012366 2189-2197. (https://doi.org/10.1056/ NEJMoa1200966)

148 Liu X. Targeting polo-like kinases: a promising therapeutic approach for cancer treatment. Translational Oncology 20158 185-195. (https:// doi.org/10.1016/j.tranon.2015.03.010)

149 Demeure MJ, Armaghany T, Ejadi S, Ramanathan RK, Elfiky A, Strosberg JR, Smith DC, Whitsett T, Liang WS, Sekar S et al. A phase I/II study of TKM-080301, a PLK1-targeted RNAi in patients with adrenocortical cancer (ACC). Journal of Clinical Oncology 201634 $2547-2547$. 
150 Khoo KH, Verma CS \& Lane DP. Drugging the p53 pathway: understanding the route to clinical efficacy. Nature Reviews Drug Discovery 201413 217-236. (https://doi.org/10.1038/nrd4236)

151 Brenner AK, Reikvam H, Lavecchia A \& Bruserud O. Therapeutic targeting the cell division cycle 25 (CDC25) phosphatases in human acute myeloid leukemia - the possibility to target several kinases through inhibition of the various CDC25 isoforms. Molecules 201419 18414-18447. (https://doi.org/10.3390/ molecules191118414)
152. Brezak MC, Kasprzyk PG, Galcera MO, Lavergne O \& Prevost GP. CDC25 inhibitors as anticancer agents are moving forward. AntiCancer Agents in Medicinal Chemistry 20088 857-862. (https://doi. org/10.2174/187152008786847701)

153 McNicol AM, Nolan CE, Struthers AJ, Farquharson MA, Hermans J \& Haak HR. Expression of p53 in adrenocortical tumours: clinicopathological correlations. J Pathol 1997181 146-152. (https://doi.org/10.1002/(SICI)1096-9896(199702)181:2<146::AIDPATH744>3.0.CO;2-7)

Received 20 November 2017

Revised version received 1 April 2018

Accepted 15 May 2018 